\title{
Investment in ecology to preserve the environment
}

\author{
Galina Semenova ${ }^{1,2,{ }^{*}}$ \\ ${ }^{1}$ Plekhanov Russian University of Economics, Stremyanny per., 36, Moscow, Russia \\ ${ }^{2}$ Moscow Region State University, Vera Voloshina St., 24, Mytishchi, Moscow Region, Russia
}

\begin{abstract}
Investing money in environmental protection measures is an investment project. The ecological problem is one of the global problems of our time. Disposal of household waste and their pollution of the environment is currently one of the most serious environmental problems in Russia. Human waste products also significantly affect the pollution of water bodies, since water that is used in cities for the needs of the population from the sewage system often enters directly into open water bodies, bypassing the system of treatment facilities, the quality of which leaves much to be desired: most of them almost cannot cope with their functions due to outdated and deteriorated equipment. In Russia, the national project "Ecology" has been adopted, since the need for the introduction of new technologies that do not harm the environment has long been acute. The subject of the study is the investment of enterprises and organizations in environmental innovations for the preservation of natural resources. The purpose of the study is the necessity and significance of investments in high-tech projects to improve the environmental situation and reduce emissions of pollutants into the air. Methodology. The financial support of the new national project "Ecology" has been studied. The companies that successfully implement the latest technologies in their production, focused on reducing the harm caused to the environment, thereby attracting investments in their projects, are highlighted. Results. Enterprises will be able to attract investments for the development of their own production only if they are attractive to investors, for whom such aspects of work as the introduction of modern technologies, taking into account the minimization of harm to the environment, are extremely important.
\end{abstract}

\section{Introduction}

Environmental problems are beginning to come to the fore today. Abnormally warm winters, growing dumps and landfills, and an increasing amount of emissions into the atmosphere - all this cannot go unnoticed. The deterioration of the environment affects not only people, but also has significant negative consequences for the Russian economy. Russia has joined the Paris Climate Agreement and launched a large-scale national project "Ecology".

\footnotetext{
${ }^{*}$ Corresponding author: angela-1309.m@yandex.ru
} 
Nornickel, Arkhangelsk PPM and Ilim are active participants in the national project. These companies are already successfully introducing the latest technologies aimed at reducing harm to the environment at their production facilities, thereby increasing the chances of obtaining foreign investment and priority rights for federal programs implemented within the framework of the national project "Ecology". On average, the annual share of environmental spending in Russia is no more than $0.8 \%$ of GDP. At the moment, Russia ranks 52nd out of 180 in the ranking of countries in the world according to the environmental efficiency index - 63.79 [2]. The three leaders are: Switzerland - 87.42, France - 83.95 and Denmark - 81.6.

Environmental Performance Index - is a combined indicator of the Yale Center for Environmental Law and Policy that measures a country's achievements in terms of environmental health and natural resource management. It is calculated using a unique methodology based on 22 indicators in 10 categories, developed by scientists at Yale University in conjunction with independent international experts. The high indicator of this index confirms the fact that the country's enterprises are engaged in solving environmental problems. The Russian index - 63.79 - is not high. But, thanks to the launched national project, there is every chance to significantly increase the country's position in the ranking.

The largest contribution to the preservation and restoration of natural resources in Russia is made by oil, metallurgical companies and representatives of the pulp and paper industry. According to the latest data, the top three are: Norilsk Nickel - on average, $4.99 \%$ of revenue is allocated to the environment, Ilim - 3.53\%, and Arkhangelsk PPM - 2.95\%. This is almost twice as much as the average in Russia $(1.9 \%)$ and almost three times more than in the European Union (1.5\%). Thus, by 2023, Norilsk Nickel, within the framework of the Northern Project, plans to invest over 123 billion rubles in measures to modernize its production to reduce harmful emissions into the atmosphere. Arkhangelsk PPM launched an updated cardboard machine, which made it possible to reduce the consumption of industrial water and electricity, and a new evaporation plant almost completely neutralized sulfurcontaining emissions. For several years Ilim has been running its own environmental program, which allows it to capture and degrease up to $85 \%$ of harmful emissions into the air, purify $100 \%$ of wastewater and use $75 \%$ of waste to generate energy in its own production [2]. Fly ash from thermal power plants is actively used for the production of structural concrete [3-6].

For the companies actively developing the environmental area within the framework of their activities, such investments are not just concern for the environment. Work on projects with a high orientation towards preserving the environment contributes to the modernization of production, the development of new approaches to the extraction of raw materials, the creation of additional jobs and the training of specialists in more modern and relevant skills in production technology.

In addition, some large foreign investors refuse to invest in companies that are not ready to take care of the environment. For example, the world's largest Norwegian Investment Fund refused to invest in plants and factories that damage the environment. The same approach to investing is practiced by the Guardian Media Group publishing holding. In other words, by paying attention to the modernization of production and reducing the negative impact on the environment, Russian enterprises increase not only their investment attractiveness for foreign companies, but also the country's overall rating.

At the same time, almost all Russian enterprises investing in solving environmental problems refer to the fact that they receive insufficient support from the state. As an example, they cite the experience of Sweden, where, since 2005, tax incentives have been introduced for energy-intensive industries that are ready to develop and implement projects to reduce energy consumption. It is tax deductions and special programs in our country that can become 
an impetus for a larger number of Russian industries to pay attention to solving environmental problems.

Of course, clear control by the state is also necessary in this area. Russia has already had a similar experience. In 1996, the Police Department for the Prevention of Environmental Offenses was established in Moscow. During the first four years, its employees initiated about 500 criminal cases and revealed more than 600 thousand administrative offenses in the field of ecology. The total amount of fines was about 20 million rubles, and the amount of damage that was prevented by the environmental police exceeded 150 million rubles. Unfortunately, in 2010, the department was completely abolished as ineffective. But the experience of other countries shows that the correct setting of priorities for the activities of such structures can bring positive results. "Green" police successfully work in Israel, Morocco, USA, Germany, Japan and a number of other countries where severe penalties are provided for violation of environmental legislation.

\section{Materials and Methods}

A simple monetary estimate of natural resources and the environmental costs of human activities is not enough. There is a constant search for answers to the following questions:

1) what is the rational ratio of environmental costs and permissible economic damage?

2) how effective are these or those environmental costs?

Environmental costs are the costs of environmental protection measures, such as reducing air pollution and water resources, land development and reclamation, etc. One of the main features of assessing the economic efficiency of environmental protection measures is that such efficiency cannot be determined on the basis of an analysis of activities only in the base year, since the restoration of the natural environment is a long process. Therefore, a distinction is made between the primary effect and the final complex socio-economic effect of environmental protection measures.

The primary effect is to reduce the impact on the environment and improve its condition. It manifests itself in a decrease in the volume and concentration of pollution in the atmosphere, water environment and soil.

The end effect is expressed in an increase in the standard of living of the population and production efficiency. Its social aspect is manifested in a decrease in the morbidity rate of the population, an improvement in recreation conditions, and the preservation of aesthetically valuable natural resources.

According to the theory of economics, investing money in environmental protection measures is an investment project. Funds in any economic system are limited, and there are always many investment options. Therefore, the basis for choosing the preferred project is a comparison in monetary terms of the required costs and the expected benefits, i.e. determination of economic efficiency.

The general rule for making an economically sound decision is the excess of the potential benefit $B$ over the cost $C$ :

$$
B-C>0
$$

The larger the difference, the more profitable the investment. However, for consideration of multi-year investment projects, when it is necessary to compare current costs and future benefits, and even taking into account inflation, this approach is not applicable. Therefore, to assess investment projects, it is customary to use the indicator of net present value (NPV), which makes it possible to measure time-varying costs with the benefits received. The project is accepted if NPV $>0$. The estimated profit from the project for a number of years is calculated by the formula: 


$$
N P V=-\sum I_{\text {нач }}+\sum_{t=1}^{n} \frac{B_{t}-C_{t}}{(1+r)^{t}},
$$

where $\mathrm{I}_{\text {in }}$ - initial investment;

$r$ - discount coefficient;

$t$ - serial number of the year;

$n$ - the total number of years required to implement the investment project as planned.

This expression does not explicitly take into account either the assessment of natural resources or the magnitude of environmental damage; they are only implied in it. If the environmental indicator, which is the sum of environmental benefits and costs, is separated as a separate component, then the expression will take the form:

$$
N P V=-\sum I_{\text {in }}+\sum_{t=1}^{n} \frac{B_{t}-C_{t} \pm E_{t}}{(1+r)^{t}},
$$

where E - environmental component (sum of environmental benefits and costs) for the $t$-th year.

This expression is currently the main one for determining the economic efficiency of the project, taking into account the environmental component and the time factor.

The choice of an investment project is a difficult and controversial issue, like everything related to the assessment of natural resources and environmental damage to the environment. In the current economic situation in our country, preference is given to projects that bring quick returns. Thus, the situation of a typical priority of today's welfare continues to develop over the costs of preventing damage to the future biosphere. As a result, long-term projects are ignored, investment in which would have a great environmental effect. The main reason for this situation at present is the high discount rates set by international organizations, banks and other creditors.

\section{NPV - net present value.}

Discounting (to discount - to receive interest in advance when allocating money on loan) - bringing economic indicators of different years to a comparable form in time or the cost of future expenses and income to the current period; establishing the current equivalent of the amount to be paid in the future.

\section{Results}

Investment in ecology (environment) is investment in the development of industry and in the country's economy. A good example is the United States, where in 1970 the Clean Air Act was passed and the Environmental Protection Agency was created. The work of this program led to significant improvements in air quality in the country, and the benefits from it were several times higher than the costs incurred by the American economy as a whole. First, the reduction of harmful impurities in the atmosphere contributed to the improvement of the quality of life of the population. Secondly, the increased standard of living contributed to the fact that the country became more attractive for emigrants and, as a result, there was a high demand for real estate, the prices of which increased significantly. And the introduction of the sulfur dioxide emissions trading system in 1990 showed a good long-term effect in reducing mortality, estimated at $\$ 134$ billion annually, while the program itself costs only $\$$ 3 billion a year. All this had a positive effect for the companies that took part in the state project - they received additional funds, which were allocated within the framework of the 
"Act", the number of highly qualified specialists increased at the expense of emigrants from other countries, and investment attractiveness increased.

Economic damage from environmental pollution in Russia reaches 4-6\% of the gross domestic product (GDP), and taking into account the consequences for human health - 15\% [1]. Among the most pressing environmental problems in Russia are air pollution from factories (17\%), landfills (15\%), and the lack of cleaning of rivers and lakes (10\%) [4].

Realizing the need to introduce technologies that do not harm the environment, the national project "Ecology" was adopted in Russia. There are many reasons for the emergence of the national project "Ecology of Russia". Ultimately, it turned out to be necessary because problems in the environmental sphere began to hinder the development of the Russian economy [9]. The national project "Ecology" identifies two key problems (table 1).

Table 1. Key problems of the national project "Ecology".

\begin{tabular}{|l|l|}
\hline \multicolumn{1}{|c|}{ Factors } & \multicolumn{1}{|c|}{ Consequences } \\
\hline $\begin{array}{l}\text { High level of air pollution in large } \\
\text { industrial centers } \\
\text { Poor drinking water quality }\end{array}$ & $\begin{array}{l}\text { Significantly contribute to the rise in } \\
\text { morbidity and mortality }\end{array}$ \\
\hline $\begin{array}{l}\text { Presence of unauthorized landfills within } \\
\text { city boundaries }\end{array}$ & $\begin{array}{l}\text { Promotes the growth of social tension in } \\
\text { society }\end{array}$ \\
\hline
\end{tabular}

The national project "Ecology" includes eleven areas. The financial support of these areas is presented in table 2 .

Table 2. Financial support of the areas of the national project "Ecology".

\begin{tabular}{|c|l|c|}
\hline No. & \multicolumn{1}{|c|}{ Name of the federal project } & $\begin{array}{c}\text { Financial support, } \\
\text { in million rubles }\end{array}$ \\
\hline 1 & "Clean country" & 124206.8 \\
\hline 2 & $\begin{array}{l}\text { "Integrated system for the management of municipal solid } \\
\text { waste" }\end{array}$ & 296223.8 \\
\hline 3 & $\begin{array}{l}\text { "Infrastructure for waste management of I - II hazard } \\
\text { classes" }\end{array}$ & 36353.3 \\
\hline 4 & "Fresh air" & 500139.8 \\
\hline 5 & "Pure water" & 245050.0 \\
\hline 6 & "Improvement of the Volga" & 205378.9 \\
\hline 7 & "Preservation of Lake Baikal" & 33944.9 \\
\hline 8 & "Preservation of unique water bodies" & 6282.8 \\
\hline 9 & $\begin{array}{l}\text { "Preservation of biological diversity and development of } \\
\text { ecological tourism" }\end{array}$ & 151009.8 \\
\hline 10 & "Preservation of forests" & 2427300.0 \\
\hline 11 & "Implementation of the best available technologies" & $\mathbf{4 0 4 1 0 4 2 . 1}$ \\
\hline & Total &
\end{tabular}

One of the main tasks of the national project is to raise funds from extrabudgetary sources. For example, the federal project "Implementation of the best available technologies" is a deep modernization of the Russian industry, the cost of which is estimated at 2.4 trillion rubles. This is exactly the amount that large industrialists need to invest in their ecological modernization [9].

Enterprises will be able to attract such impressive sums for the development of their own production only if they are attractive to investors for whom such aspects of work as the introduction of modern technologies, taking into account the minimization of harm to the environment, are extremely important. On the one hand, it looks like a vicious circle. On the other hand, it is the new principles of production that have the least negative consequences for the environment that are the key to investment attractiveness and, as a result, successful 
further development. Such conditions are dictated by the modern market, and Russian enterprises are successfully fulfilling them.

\section{Discussion}

"Ecology should be financially attractive. In 2020, three hundred large Russian companies were supposed to switch to eco-technology", - agrees Sergei Ivanov, special representative of the President of the Russian Federation for environmental protection, ecology and transport. And by 2021, all Russian companies will switch to ecotechnologies, including transport.

"We store only $3 \%$ of waste, and the issue is not only regulatory pressure on us", explains Alexey Mordashov, Chairman of the Board of Directors of Severstal PJSC. "Such a strategy is a global trend".

Today the experience of Finland is underestimated in the world, it needs to be rethought and implemented. The cleaning of the Baltic Sea region is an example that has been successfully used in Russia.

"The main question is how to involve consumers?" - says Elisa Markula, CEO of Tikkurila Oyj. - "They are a key element of the system, they are interested in sustainable development, all consumers want to know how the goods they buy were produced, so there is a great demand for the production of eco-goods. And Russian consumers are no exception".

After all, the main thing in the problem is that we are the first generation to experience climate change, but we are also the last who can do something.

"Today the business has entered into agreements with the regions, with the Federal Service for Supervision of Natural Resource Usage, with the ministry on investments in the amount of more than 130 billion rubles in issues related to greening and preserving the natural environment," said Valentik. For example, Rusal plans to invest over 1.2 billion rubles in the ecology of the Krasnoyarsk Territory. Everyone agrees that it is necessary to attract both state and foreign investments to the environment, as well as to use more and more environmental technologies.

\section{Conclusions}

There are many reasons for environmental pollution, the human factor is not always the fault of this. Most of all, natural disasters violate the harm to clean water bodies. But the most common sources of water pollution are industrial and domestic wastewater. Having not passed the system of cleaning from chemical harmful substances, wastewater, falling into the reservoir, provokes an ecological disaster. It is advisable to form environmental projects in the form of investment projects, i.e. based on calculations of costs and benefits from investments in the real sector of the economy.

The issue of the lack of environmental innovations should be resolved through the general innovation policy of the state. Therefore, with high efficiency and low cost, achieving environmental goals remains a top priority.

Additional tax breaks for environmental R\&D will encourage investment and innovation, but not fundamental discoveries. In the future, the environmental tax introduced in Russia should be aimed directly at eliminating environmental damage, and not stimulating innovation with its benefits [7]. Without the timely introduction of innovative technologies for waste recycling, the planet will soon turn into a huge dump and become unfit for the existence of not only people, but all living beings [8]. One of the most effective ways that air protection from pollution should include is the establishment of a system for the disposal of 
all waste or their recycling . For this, enterprises need the latest technologies aimed at reducing environmental damage, as well as investments for the implementation of these new environmental projects $[9,10]$.

Implementation of 11 national projects in Russia during 2019-2024 is the first step towards a comprehensive solution of socio-economic and environmental problems, which is consistent with the principles and goals of sustainable development. But the results of the study showed that the implementation of the set of measures of the national project "Ecology" will not significantly change the environmental situation in Russia. The reason is that this project is mainly aimed at combating the consequences (reducing emissions into the atmosphere and discharges of pollutants into water bodies, combating soil erosion, etc.), and not at identifying the causes of the development of degradation processes.

\section{References}

1. V.N. Krasnoshchekov, D.G. Olgarenko, Environmental Engineering 2, 6-12 (2019)

2. A.E. Evlanov, Investments in ecology as an investment in the future (Intek-Stroy LLC)

3. Z. Bonić, G.T. Curčć, M. Trivunić, N. Davidović, N. Vatin, Some methods of protection of concrete and reinforcment of reinforced-concrete foundations exposed to environmental impacts, Procedia Eng. 117 (2015) 419-430. https://doi.org/10.1016/j.proeng.2015.08.189.

4. Y. Barabanshchikov, I. Fedorenko, S. Kostyrya, K. Usanova, Adv. Intell. Syst. Comput. 983 858-866 (2019) https://doi.org/10.1007/978-3-030-19868-8_84.

5. K. Usanova, Y.G. Barabanshchikov, Cold-bonded fly ash aggregate concrete, Mag. Civ. Eng. 95 104-118 (2020) https://doi.org/10.18720/MCE.95.10.

6. K. Usanova, Properties of Cold-Bonded Fly Ash Lightweight Aggregate Concretes, Lect. Notes Civ. Eng. 70 507-516 (2020) https://doi.org/10.1007/978-3-030-42351344 .

7. G. Semenova, E3S Web of Conferences 91, 08047 (2019) https://doi.org/10.1051/e3sconf/20199108047

8. G. Semenova, E3S Web of Conferences 138, 02012 (2019) https://doi.org/10.1051/e3sconf/201913802012

9. G. Semenova, E3S Web of Conferences 157, 02023 (2020) https://doi.org/10.1051/e3sconf/202015702023

10. G. Semenova, E3S Web of Conferences 217, 11004 (2020) https://doi.org/10.1051/e3sconf/202021711004 